\title{
Late Holocene lithic points from a Southern Brazilian mound: The Pororó site
}

João Carlos Moreno de Sousa ${ }^{1, \star}$ and Anderson Marques Garcia ${ }^{2}$

How to cite: Moreno de Sousa, J and Marques Garcia, A. Late Holocene lithic points from a Southern Brazilian mound: The Pororó site. Papers from the Institute of Archaeology, 2022, 32(1): pp. 1-18. DOI: https://doi.org/10.14324/111.444.2041$\underline{9015.1186}$

Published: 19/01/2022

\section{Peer Review:}

This article has been peer reviewed through the journal's standard double-blind review.

\section{Copyright:}

(C) 2022, The Author(s). This is an Open Access article distributed under the terms of the Creative Commons Attribution License (CC-BY) 4.0 https://creativecommons.org/licenses/by/4.0/, which permits unrestricted use, distribution and reproduction in any medium, provided the original author and source are credited • DOI: https://doi.org/10.14324/111.444.2041-9015.1186.

\section{Open Access:}

Papers from the Institute of Archaeology is a peer-reviewed open access journal.

*Correspondence: jcmorenodesousa@usp.br

${ }^{1}$ Laboratório de Estudos Evolutivos Humanos, Instituto de Biociências, Universidade de São Paulo

2 Departamento de Arqueologia, Instituto de Filosofia e Ciências Humanas, Universidade do Estado do Rio de Janeiro 


\title{
RESEARCH PAPER
}

\section{Late Holocene lithic points from a Southern Brazilian mound: The Pororó site}

\author{
João Carlos Moreno de Sousa and Anderson Marques Garcia
}

\begin{abstract}
Most lithic industries associated with hunter-gatherer groups in Eastern South America, especially the ones with points present, date to the Early Holocene, with some minor industries and lithic points typologies persisting until the Middle Holocene and, more rarely, until the Late Holocene. This is the case for the Garivaldinense lithic industry associated points typologies. In this article we present the technological analysis of the points identified at the Pororó site, located in central Rio Grande do Sul State, Brazil. The site is an artificial mound dated to around 2,500 BP. We applied an established protocol for analysis of stemmed points considering metric, morphological and technological features that allowed us to classify the artefacts in typologies. We identified two types of points associated to the Garivaldinense lithic industry: the Montenegro and Garivaldinense types. We have also identified a new type that has never been described before and proposed to refer to it as the Pororó type. At least one Pay Paso point was identified at the site, although this type of point is not yet known at other sites of this region and chronology. The results indicate persistence of the Garivaldinense Culture from the Early to Late Holocene, as well as technological innovation during the Late Holocene.
\end{abstract}

Keywords: Lithic Technology; Lithic Points; Late Holocene; South America; Archaeological Mounds; Hunter-Gatherers

\section{Introduction and background}

The diversity of lithic points associated with hunter-gatherer industries in Southern Brazil has only started to be understood in the last decade, after researchers start questioning the currently outdated notion of "Umbu Tradition" (see, for example, Okumura \& Araujo 2016; Moreno de Sousa \& Okumura 2018; Garcia 2019a; Moreno de Sousa 2020, for a review of the subject). Although much work remains to be done, technological studies on Early Holocene sites revealed five types of points, of which three are associated with the same archaeological culture. The Garivaldinense Culture is characterised by the recurrent presence of Garivaldinense points, Montenegro points and Brochier points at sites dating from the Early to Middle Holocene in Central and Eastern Rio Grande do Sul State, Brazil. The fourth 
type of point, known as Star type points, are known from findings in Paraná state and are associated with the Tunas Culture. The last type is known as the Rioclarense type, and is associated with the Rioclarense culture (Moreno de Sousa 2020; Moreno de Sousa \& Okumura 2020). These studies have corroborated the hypothesis of a greater diversity of lithic industries in southern Brazil than previously recognised.

The Garivaldinense Culture was firstly described in the Garivaldino Rockshelter Site (a.k.a. RS-Tq-58 site), located in Rio Grande do Sul state (Mentz-Ribeiro \& Ribeiro 1999; Cheliz et al. 2020; Moreno de Sousa \& Okumura 2020). Among the lithic types found, the Garivaldinense type points are the most common. Their length varies from $25-45 \mathrm{~mm}$, their width from $15-25 \mathrm{~mm}$, and their thickness from 5-9mm. Their width-thickness proportion varies from 2.1-3.1:1. In morphological terms, they usually present triangular bodies with irregular or straight edges, straight shoulders, and straight or bifurcated or convex stems. In technological terms, they are produced using the bifacial reduction method and the percussion technique, finished by pressure retouching. Reduction negatives are usually organised as selectivetrespassed or convergent untrespassed. However, some points are not reduced at all, in cases where thin flat flakes are just retouched. Here we refer to trespassed negatives as those which take more than half of the artefact width, which is different from overshot negatives. The latter refers only to negatives that take the entire width of the artefact, even removing a little bit of the opposite edge. Overshot flaking is not observed in these points.

Brochier points are also common, but in lower frequency in relation to the Garivaldinense ones. Their length varies from $22-34 \mathrm{~mm}$, their width from $9-15 \mathrm{~mm}$, and their thickness from 3-7mm. Their width-thickness proportion varies from 1.72.9:1. In morphological terms, they are usually lanceolate, tapered or irregularly shaped, and unstemmed. In technological terms, they are produced by retouching of agate thin flakes.

The Montenegro points are the least common type of point found associated with the Garivaldinense culture. Their length varies from $20-36 \mathrm{~mm}$, their width from 10 $16 \mathrm{~mm}$, and their thickness from 5-7mm. Their width-thickness proportion varies from 2.1-2.5:1. In morphological terms, they usually present a triangular bladeshaped body with straight but serrated edges and a bifurcated stem. In technological 
terms, they are produced using the bifacial method and the pressure flaking technique, such that negative scars form a median ridge.

According to Moreno de Sousa (2020), many other sites from this region would also probably become affiliates as part of the Garivaldinense industry once technological studies on the lithic points begin to be conducted. In this study we present new technological data from the Pororó site, located in the proposed Garivaldinense coverage area, and presenting at least two of the three types of points associated to this Paleoamerican culture.

\section{Pororó site characterisation}

The Pororó site is an artificial mound located in central Rio Grande do Sul State (Brazil), in the municipality of Pinhal Grande, $10 \mathrm{~km}$ from the right margin of the Jacuí river (Figure 1), atop of the Serra Geral formation between the valleys of Jacuí tributaries, but still with the Lajeado Pororó valley. The site was first recorded by the owner of the farm where the site is located, Mr. Lucas Somavilla. The owner had previously found some archaeological materials on surface, such as bolas (a.k.a. boleadeiras) and lithic points, in the region. According to him, small concentrations of materials were also found during the building of houses and artificial lakes (weirs) in the farm. However, it was only between 1998 and 2002 that he found a substantial concentration of archaeological materials, during the expansion of his house (Figure 2). Somavilla, interested in the study of his findings, contacted the team of archaeologists of the former Laboratory of Archaeological Studies and Research of the Federal University of Santa Maria (LEPA-UFSM).

Somavilla generously donated his findings to the LEPA-UFSM. The material has been recently moved to the Museum of Pinhal Grande. The site excavations were carried out in 2010, directed by Professor Saul Milder (Figure 3). The excavations revealed an anthropic construction of the mound. The most relevant features in the identification of the mound construction were the presence of boulders and other rock fragments used as building materials and, especially, the artificial accumulation of the typical archaeological "dark earth" - dark humic clay sediment formed by human activities and high presence of organic material (Figure 4). The excavation reached a maximum of $42 \mathrm{~cm}$ in depth and a homogeneous stratigraphy. A fixed anvil was also identified in the basalt outcrop next to the mound (Garcia 2016; 2020). 


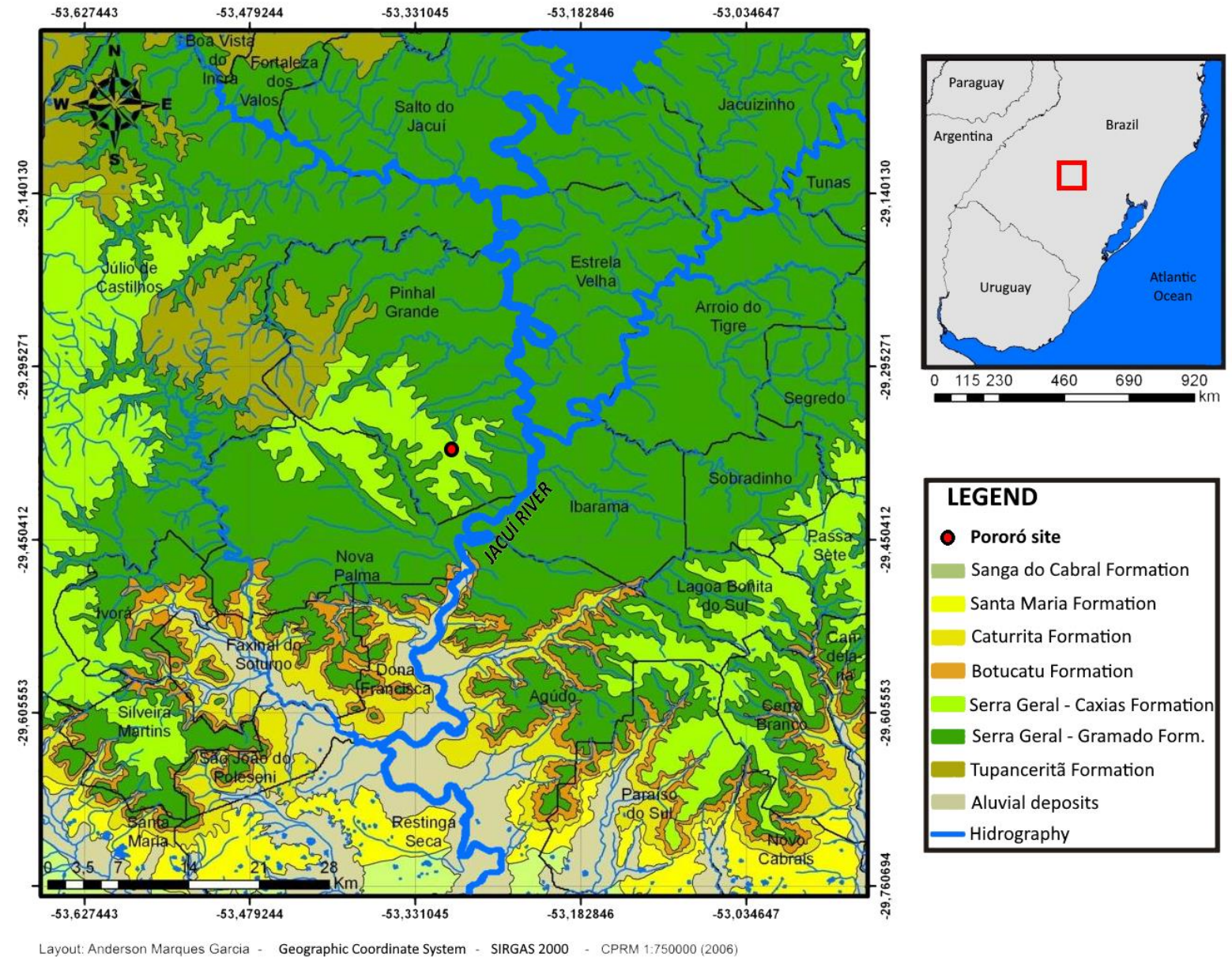

Figure 1. Location of the Pororó site in Southern Brazil and geological formations in the region.

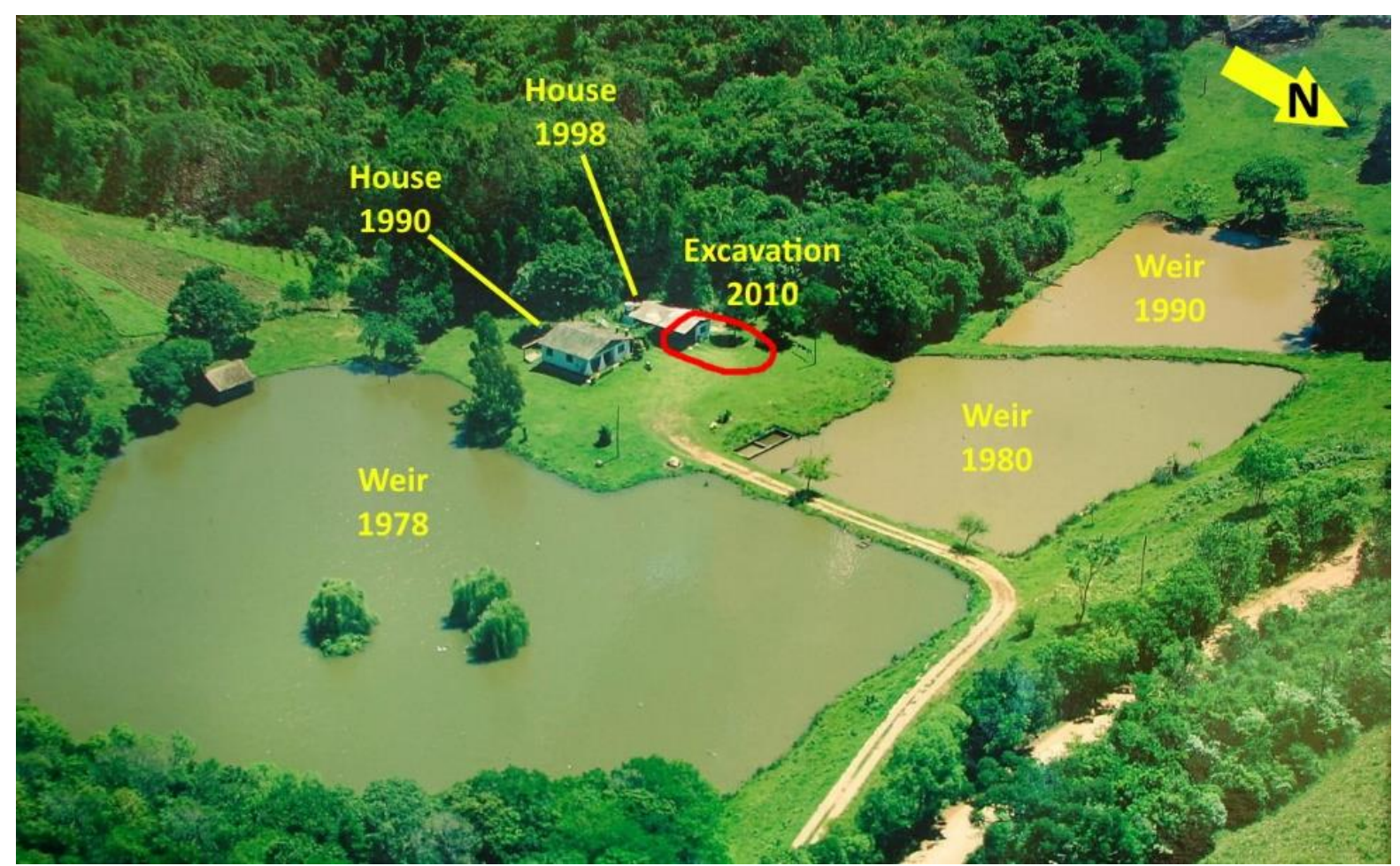

Figure 2. Chronology of constructions and excavation (in red) at the Pororó site and its surroundings since 1978. 


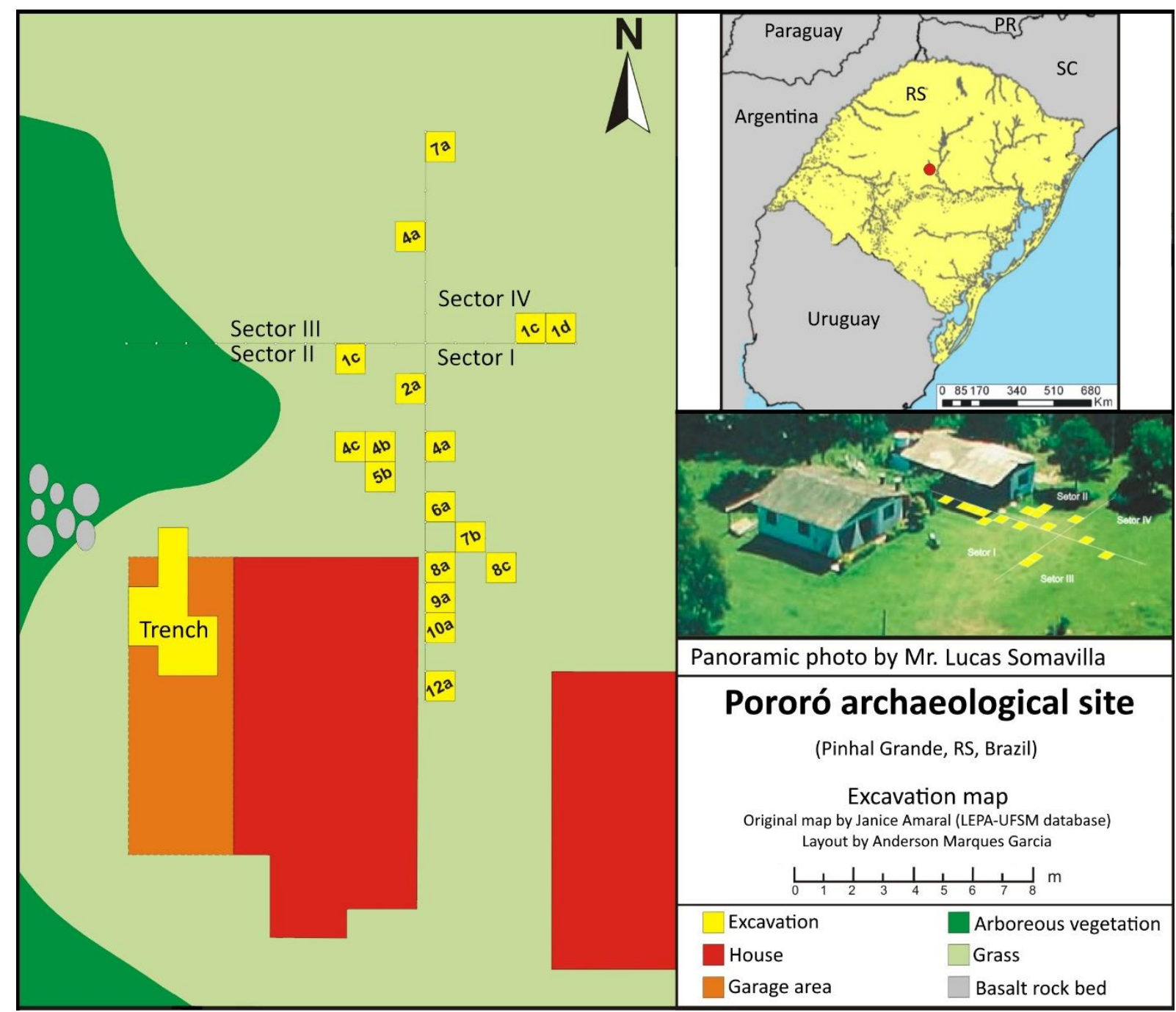

Figure 3. Excavation map of the Pororó mound site.

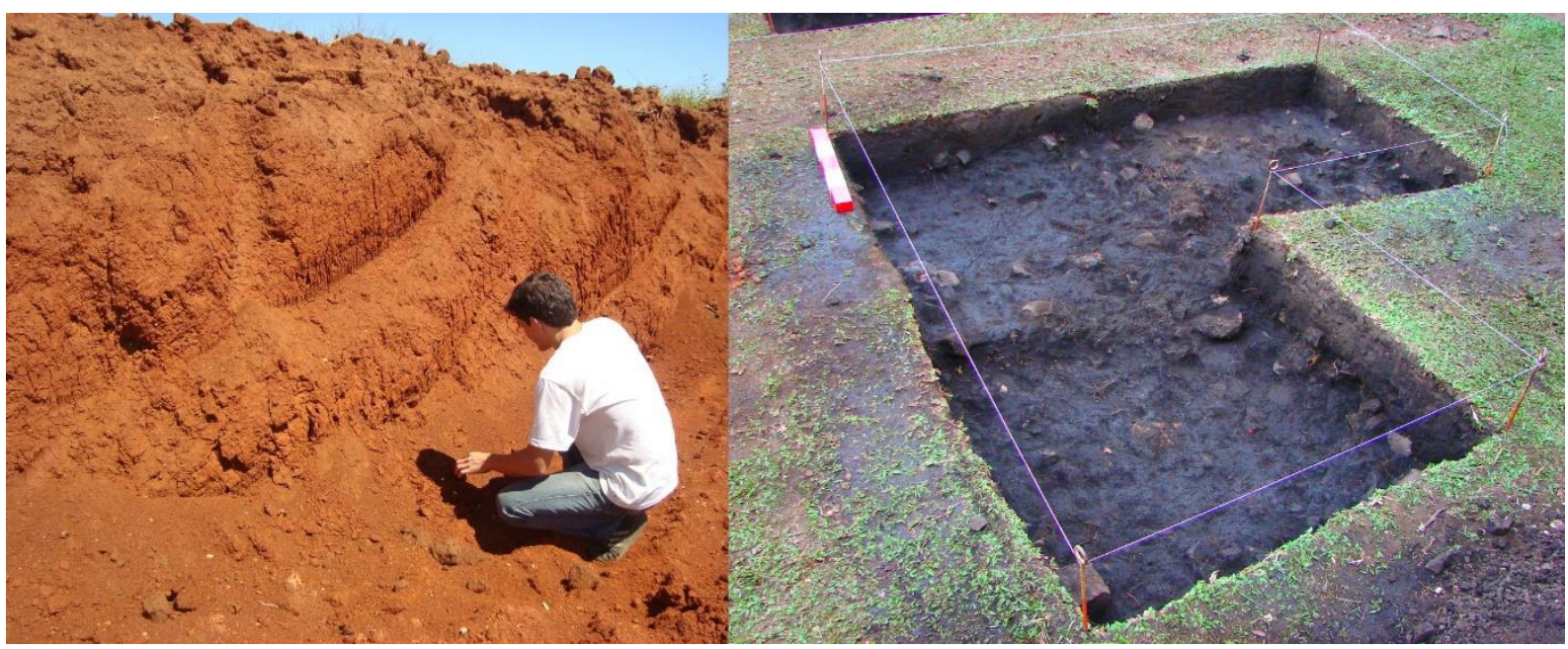

Figure 4. Left: Typical reddish clay sediment found in the surrounding areas of the Pororó site. Right: Archaeological "dark earth" from the centre of the excavation area (excavation unities 4b, $4 c$ and $5 b)$. 
Table 1. Date sample from the Pororó site.

\begin{tabular}{cccccc}
\hline Sample number & $\begin{array}{c}\text { Excavation } \\
\text { unity }\end{array}$ & Depth $(\mathbf{c m})$ & $\begin{array}{c}\text { Dating } \\
\text { method }\end{array}$ & $\begin{array}{c}{ }^{14} \mathbf{C} \text { date } \\
\mathbf{( B P})\end{array}$ & $\begin{array}{c}\text { SHCal 20 } \\
\mathbf{( 9 5 . 4 \%} \text { probability) }\end{array}$ \\
\hline BETA-319627 & $8 \mathrm{a}$ & 20 & AMS & $2450 \pm 30$ & $2699-2346$ \\
\hline
\end{tabular}

\section{Materials and methods}

A total of 10,026 of lithic vestiges were originally identified, of which $52.9 \%$ was described as construction materials for the mound. The remainder were identified as flakes or fragments from tool production (Garcia 2020). The artefact assemblage is composed by five pyramidal cores, two scrapers, 27 points, one point recycled as a scraper, three points fragments, and 11 bifacial preforms. Our study focused on the technology of the 27 points and the classification of them into types. Of the 28 points, 20 were found by Mr. Somavilla (including the one which had been recycled as scraper). According to him, they were found when digging to flattening the terrain for the construction of the second house (west on the map). The other eight points were found during the excavations conducted by Professor Saul Milder, all which were discovered in southern zone of the mound (close to the second house).

Previously, Garcia (2019b) presented a diachronic description - also referred to by some authors as diacritic analysis - of each one of these points. In this study, we followed procedures for the technological study outlined by Moreno de Sousa \& Okumura (2020). Protocols include the observation and measurement of many metric, morphological and technological attributes, bivariate and multivariate statistics, as well as the classification of artefacts into types according to their features' patterns. We do not aim to present a complete description of this method here, since it has already been described in Moreno de Sousa \& Okumura (2020) work.

In this study, the statistical analysis (descriptive, frequency and bivariate or multivariate analysis) was not performed due the small size of the samples. We considered that the number of specimens of each type were insufficient for an accurate regional comparison of the technology by bivariate analysis to the dataset presented by Moreno de Sousa \& Okumura (2020). Other types of analysis (e.g., principal component analysis) that consider only the metrical attributes could be performed, but they do not take into account technological attributes. Since our objective in this paper is to discuss the technology of the artefacts, these other types of quantitative analysis were not carried out. The data presented in this analysis is 
available to any researcher to use for such purposes, and we welcome researchers to use these data.

In order to classify these points into previously known types, we considered the individual cultural patterns (metric, morphological and technological attributes) of each specimen. The features observed in each artefact are presented in tables.

\section{Data results}

We identified three distinct types among the points discovered at the Pororo site: Garivaldinense type (Figure 5; $\mathrm{n}=11$ ), Montenegro type (Figure 6; $\mathrm{n}=8$ ), and a third, previously undefined, type (Figure $7 ; \mathrm{n}=5$ ) which we propose to call the "Pororó type". We also identified three points that could not be classified into any of these three types (Figure 07). In fact, one of these points (Por-27) seems to present the standard features of Pay Paso points, usually found in northern Uruguay. And at least one point was reshaped as a scraper (Figure 07).
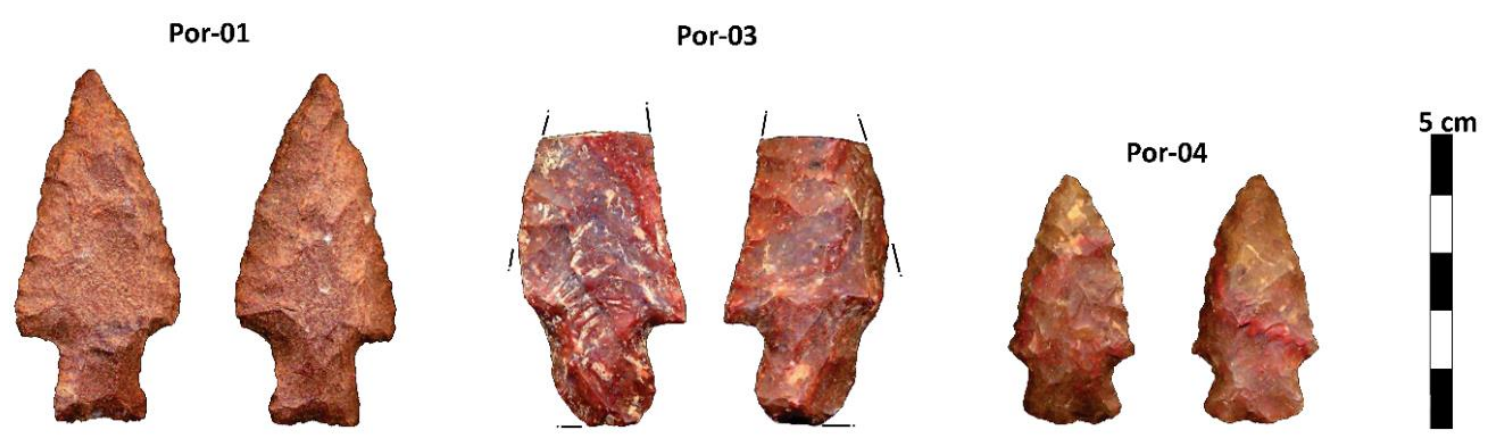

Por-07

Por-08

Por-18

Por-19
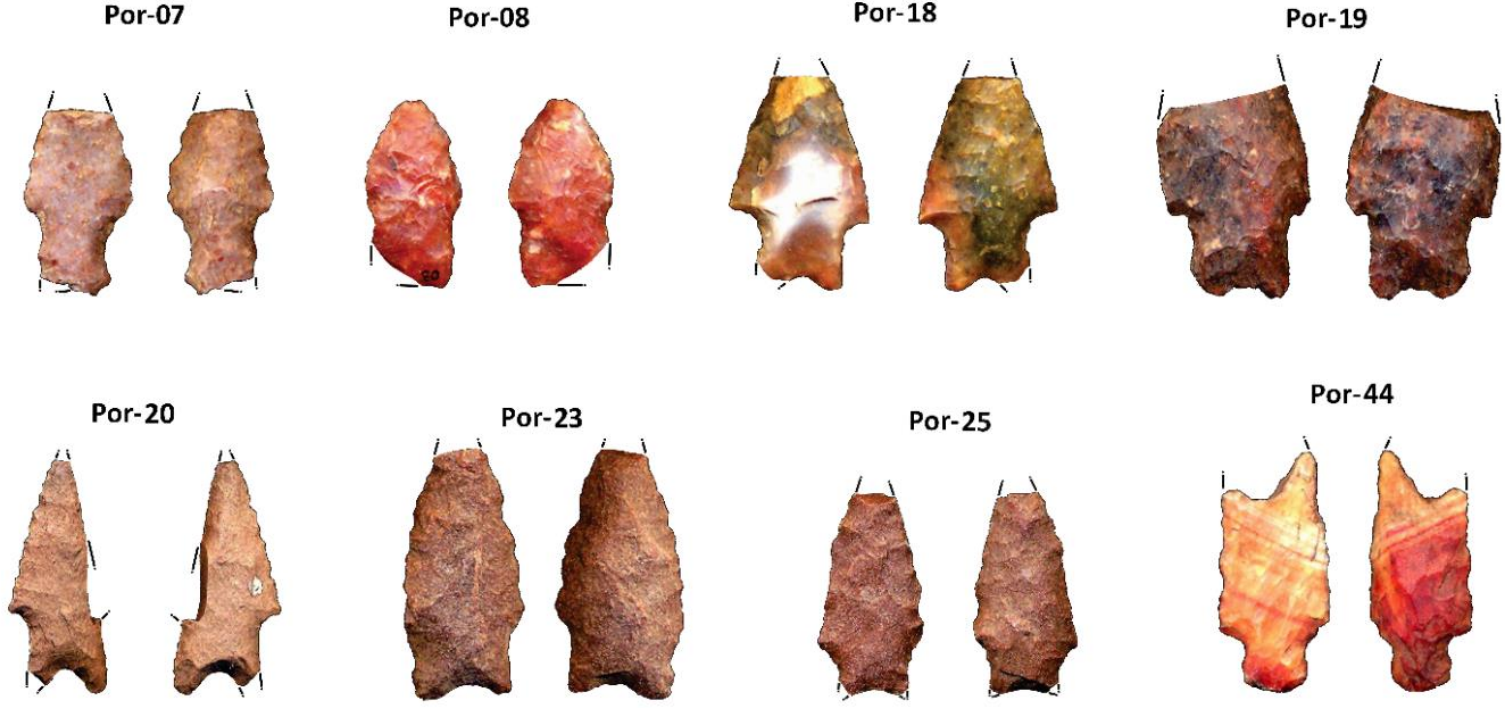

Figure 5. Garivaldinense type points found at the Pororó site. Por-08 has been reshaped, and was found in the trench. Por-19 and Por-44 have not been finished. 


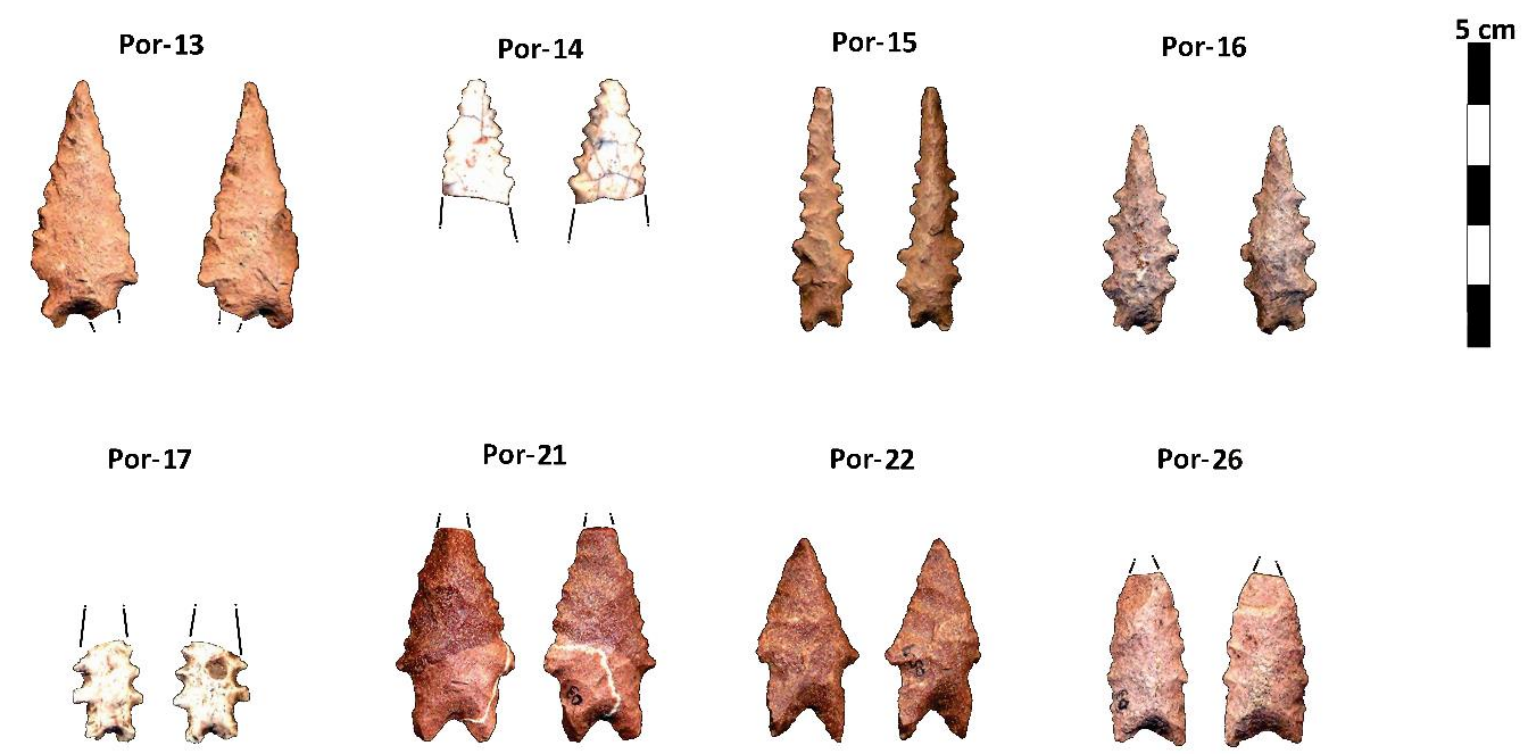

Figure 6. Montenegro type points from the Pororó site. Por-14 was found in excavation 7b, between 15 and $20 \mathrm{~cm}$ of depth. Por-16 was found in excavation 4c, between 20 and $25 \mathrm{~cm}$ of depth. Por-21 and Por-26 were found in the trench excavation. Por-22 was found in excavation 6a, between 30 and $35 \mathrm{~cm}$ of depth.
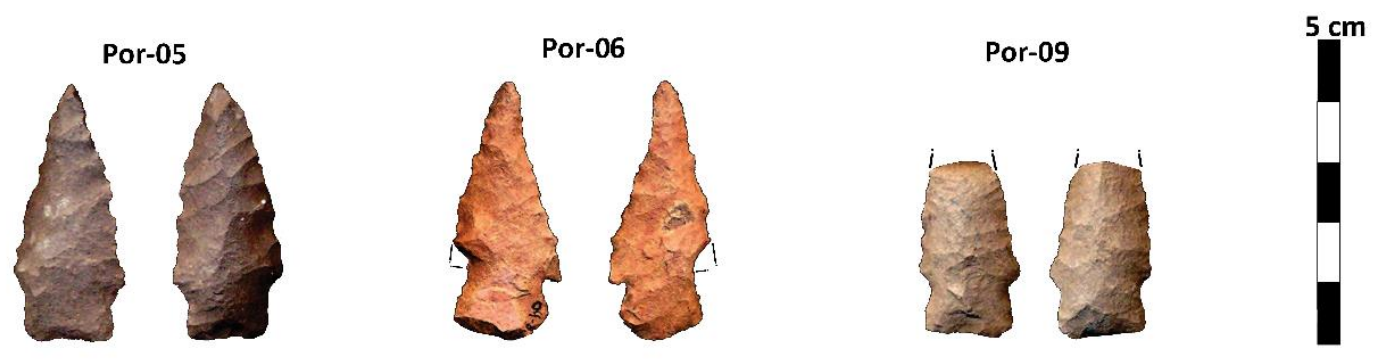

Por-11

Por-12
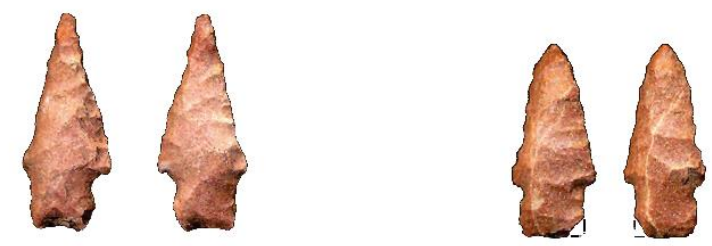

Figure 7. Pororó type points from the Pororó site. Por-06 was found in the excavation 4a, between 35 and $40 \mathrm{~cm}$ of depth. 


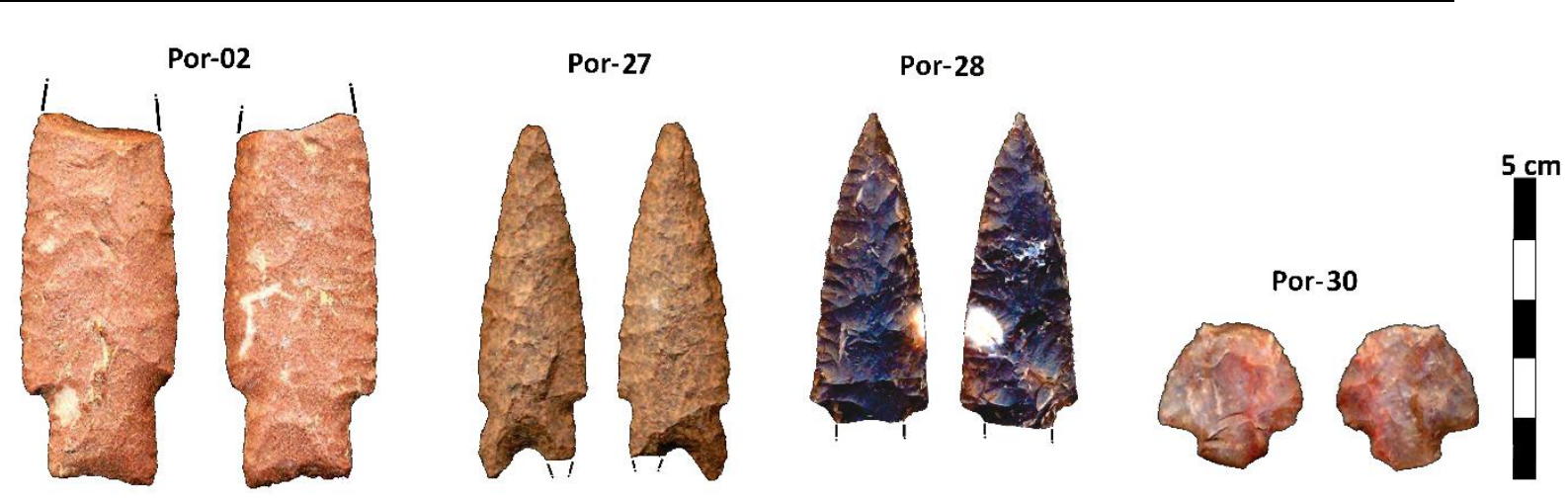

Figure 8. Lithic points presenting distinct patterns in the Pororó site. Por-02 and Por-28: Unidentified types. Por-27: Pay Paso type. Por-30: point recycled as a scraper. Por-28 was found in the excavation unity $8 \mathrm{c}$, between 30 and $35 \mathrm{~cm}$ of depth.

Table 2 presents the features of the Garivaldinense type points from the Pororó site. Table 3 presents the features for the Montenegro type, Table 4 presents the features for the Pororó type, and Table 5 presents the features for the remaining points.

\section{Interpretations of the data}

Although we could classify most of the points into the Garivaldinense and the Montenegro types, some differences in relation to the original definition of Moreno de Sousa \& Okumura (2020) could be noted (Figure 9).

In general, the Garivaldinense points from the Pororó site are relatively thinner, with proportions that are usually larger than 3.1:1. This could be related to the quality of raw material, since the points larger than 3.1:1 are made of flint or were made on flakes that were thin enough and were not reduced.

The Montenegro point are the ones which present the most differences, particularly with regard to size and shape. Points that present the usual Montenegro body shape are bigger in comparison with the ones used for the definition of the type (the Montenegro "holo-types"). This could be simply a regional or chronological variation, or suggest that points of this type became longer through time. Some points present bodies that are less "blade-like" and wider. This could also be a chronological variation of this type. 
Table 2. Metric, morphological, and technological features of finished Garivaldinense points from Pororó site.

\begin{tabular}{|c|c|c|c|c|c|c|c|c|c|}
\hline Attributes & Por-01 & Por-03 & Por-04 & Por-07 & Por-08 & Por-18 & Por-20 & Por-23 & Por-25 \\
\hline Raw material & $\begin{array}{l}\text { Silicified } \\
\text { sandstone }\end{array}$ & Flint & Flint & Flint & Flint & Flint & $\begin{array}{c}\text { Silicified } \\
\text { sandstone }\end{array}$ & $\begin{array}{c}\text { Silicified } \\
\text { sandstone }\end{array}$ & $\begin{array}{c}\text { Silicified } \\
\text { sandstone }\end{array}$ \\
\hline Total length (mm) & 59 & - & 42 & - & 31 & 47 & 42 & 48 & 40 \\
\hline Total width (mm) & 28 & 32 & 20 & 18 & 16 & 23 & 17 & 20 & 18 \\
\hline $\begin{array}{l}\text { Total thickness } \\
(\mathrm{mm})\end{array}$ & 6 & 7 & 6 & 4 & 5 & 6 & 6 & 7 & 6 \\
\hline $\begin{array}{l}\text { Width:thickness } \\
\text { proportion }\end{array}$ & 4.6:1 & 4.6:1 & $3.3: 1$ & $4.5: 1$ & 3.21 & $3.8: 1$ & $2.8: 1$ & $2.8: 1$ & $3: 1$ \\
\hline Body length (mm) & 45 & - & 33 & - & 21 & 34 & 30 & 35 & 32 \\
\hline Stem length (mm) & 14 & 17 & 9 & 15 & 10 & 13 & 12 & 13 & 8 \\
\hline $\begin{array}{l}\text { Active edges length } \\
(\mathrm{mm})\end{array}$ & 47 & - & 32 & - & 19 & 35 & 31 & 36 & 33 \\
\hline $\begin{array}{l}\text { Shoulders width } \\
(\mathrm{mm})\end{array}$ & 28 & 32 & 20 & 18 & 16 & 23 & 17 & 20 & 18 \\
\hline Neck width (mm) & 14 & 16 & 13 & 11 & 12 & 13 & 13 & 15 & 12 \\
\hline Stem width (mm) & 15 & 18 & 16 & 13 & 14 & 15 & 15 & 17 & 13 \\
\hline Body shape & Triangle & Triangle & Triangle & Triangle & Triangle & Triangle & Triangle & Triangle & Triangle \\
\hline Edge lineation & Straight & Straight & Convex & Irregular & Convex & Convex & Straight & Convex & Irregular \\
\hline Shoulder lineation & Incurvate & Straight & Expanded & Irregular & Straight & Straight & Straight & Straight & Straight \\
\hline Neck lineation & Right & Right & Obtuse & Obtuse & Obtuse & Obtuse & Obtuse & Obtuse & Obtuse \\
\hline Stem shape & Concave & Concave & Fan & Concave & Concave & Bifurcate & Bifurcate & Concave & Concave \\
\hline Blank type & Flake & Flake & Undefined & Flake & Undefined & Flake & Flake & Undefined & Undefined \\
\hline Reduction method & Bifacial & Bifacial & Bifacial & Unifacial & Bifacial & Bifacial & Bifacial & Bifacial & Bifacial \\
\hline $\begin{array}{l}\text { Reduction } \\
\text { technique }\end{array}$ & Percussion & Percussion & Percussion & Percussion & Percussion & Percussion & Percussion & Percussion & Pressure \\
\hline Retouch method & Bifacial & Bifacial & Bifacial & Bifacial & Bifacial & Bifacial & Bifacial & Bifacial & Bifacial \\
\hline Retouch technique & Pressure & Pressure & Pressure & Pressure & Pressure & Pressure & Pressure & Pressure & Absent \\
\hline $\begin{array}{l}\text { Organisation of } \\
\text { body scars }\end{array}$ & $\begin{array}{c}\text { Convergent } \\
\text { untrespassed }\end{array}$ & $\begin{array}{l}\text { Selective } \\
\text { trespassed }\end{array}$ & $\begin{array}{l}\text { Selective } \\
\text { trespassed }\end{array}$ & $\begin{array}{l}\text { Selective } \\
\text { trespassed }\end{array}$ & $\begin{array}{l}\text { Selective } \\
\text { trespassed }\end{array}$ & $\begin{array}{c}\text { Convergent } \\
\text { untrespassed }\end{array}$ & $\begin{array}{l}\text { Selective } \\
\text { trespassed }\end{array}$ & $\begin{array}{l}\text { Selective } \\
\text { trespassed }\end{array}$ & $\begin{array}{l}\text { Selective } \\
\text { trespassed }\end{array}$ \\
\hline $\begin{array}{l}\text { Organisation of } \\
\text { stem scars }\end{array}$ & $\begin{array}{l}\text { Convergent } \\
\text { trespassed }\end{array}$ & $\begin{array}{l}\text { Convergent } \\
\text { trespassed }\end{array}$ & $\begin{array}{l}\text { Selective } \\
\text { trespassed }\end{array}$ & $\begin{array}{l}\text { Selective } \\
\text { trespassed }\end{array}$ & $\begin{array}{l}\text { Selective } \\
\text { trespassed }\end{array}$ & $\begin{array}{l}\text { Convergent } \\
\text { trespassed }\end{array}$ & $\begin{array}{l}\text { Selective } \\
\text { trespassed }\end{array}$ & $\begin{array}{l}\text { Selective } \\
\text { trespassed }\end{array}$ & $\begin{array}{l}\text { Selective } \\
\text { trespassed }\end{array}$ \\
\hline
\end{tabular}


Table 3. Metric, morphological, and technological features of the Montenegro points from Pororó site).

\begin{tabular}{|c|c|c|c|c|c|c|c|c|}
\hline Attributes & Por-13 & Por-14 & Por-15 & Por-16 & Por-17 & Por-21 & Por-22 & Por-26 \\
\hline Raw material & Rhyolite & Basalt & Flint & Flint & $\begin{array}{l}\text { Silicified } \\
\text { sandstone }\end{array}$ & $\begin{array}{c}\text { Silicified } \\
\text { sandstone }\end{array}$ & $\begin{array}{c}\text { Silicified } \\
\text { sandstone }\end{array}$ & $\begin{array}{c}\text { Silicified } \\
\text { sandstone }\end{array}$ \\
\hline Total length (mm) & 41 & 40 & 34 & - & 43 & 33 & 34 & 34 \\
\hline Total width (mm) & 18 & 10 & 12 & 12 & 20 & 17 & 16 & 13 \\
\hline $\begin{array}{l}\text { Total thickness } \\
(\mathrm{mm})\end{array}$ & 5 & 5 & 5 & 5 & 8 & 5 & 6 & 6 \\
\hline $\begin{array}{l}\text { Width:thickness } \\
\text { proportion }\end{array}$ & $3.6: 1$ & $2: 1$ & $2.4: 1$ & $2.4: 1$ & $2.5: 1$ & $3.4: 1$ & $2.7: 1$ & $2.2: 1$ \\
\hline Body length (mm) & 33 & 34 & 28 & - & 28 & 22 & 26 & 23 \\
\hline Stem length (mm) & 8 & 6 & 6 & 6 & 15 & 11 & 8 & 11 \\
\hline $\begin{array}{l}\text { Active edges length } \\
(\mathrm{mm})\end{array}$ & 34 & 33 & 28 & - & 27 & 21 & 27 & 24 \\
\hline $\begin{array}{l}\text { Shoulders width } \\
(\mathrm{mm})\end{array}$ & 18 & 10 & 12 & 12 & 20 & 17 & 20 & 13 \\
\hline Neck width (mm) & 12 & 6 & 7 & 7 & 13 & 11 & 13 & 11 \\
\hline Stem width (mm) & 14 & 6 & 7 & 8 & 13 & 13 & 14 & 12 \\
\hline Body shape & Triangle & Triangle-blade & Triangle-blade & Triangle-blade & Triangle & Triangle & Triangle & Triangle \\
\hline Edge lineation & Serrated-straight & Serrated-straight & Serrated-straight & Serrated-straight & Serrated-straight & Straight & Serrated-straight & Serrated-straight \\
\hline Shoulder lineation & Straight & Straight & Straight & Straight & Straight & Straight & Straight & Straight \\
\hline Neck lineation & Right & Obtuse & Obtuse & Obtuse & Obtuse & Obtuse & Obtuse & Obtuse \\
\hline Stem shape & Bifurcate & Bifurcate & Bifurcate & Bifurcate & Bifurcate & Bifurcate & Bifurcate & Bifurcate \\
\hline Blank type & Flake & Undefined & Flake & Undefined & Flake & Undefined & Undefined & Undefined \\
\hline Reduction method & Unifacial & Bifacial & Bifacial & Bifacial & Bifacial & Bifacial & Bifacial & Bifacial \\
\hline $\begin{array}{l}\text { Reduction } \\
\text { technique }\end{array}$ & Percussion & Pressure & Pressure & Pressure & Pressure & Pressure & Pressure & Pressure \\
\hline Retouch method & Bifacial & Absent & Absent & Absent & Absent & Absent & Absent & Bifacial \\
\hline Retouch technique & Pressure & Absent & Absent & Absent & Absent & Absent & Absent & Pressure \\
\hline $\begin{array}{l}\text { Organisation of } \\
\text { body scars }\end{array}$ & $\begin{array}{l}\text { Parallels with } \\
\text { median ridge }\end{array}$ & $\begin{array}{l}\text { Parallels with } \\
\text { median ridge }\end{array}$ & $\begin{array}{l}\text { Parallels with } \\
\text { median ridge }\end{array}$ & $\begin{array}{l}\text { Parallels with } \\
\text { median ridge }\end{array}$ & $\begin{array}{l}\text { Parallels with } \\
\text { median ridge }\end{array}$ & $\begin{array}{l}\text { Parallels with } \\
\text { median ridge }\end{array}$ & $\begin{array}{l}\text { Parallels with } \\
\text { median ridge }\end{array}$ & $\begin{array}{l}\text { Parallels with } \\
\text { median ridge }\end{array}$ \\
\hline $\begin{array}{l}\text { Organisation of } \\
\text { stem scars }\end{array}$ & $\begin{array}{l}\text { Convergent } \\
\text { trespassed }\end{array}$ & $\begin{array}{l}\text { Convergent } \\
\text { trespassed }\end{array}$ & $\begin{array}{l}\text { Convergent } \\
\text { trespassed }\end{array}$ & $\begin{array}{l}\text { Convergent } \\
\text { trespassed }\end{array}$ & $\begin{array}{l}\text { Convergent } \\
\text { trespassed }\end{array}$ & $\begin{array}{l}\text { Convergent } \\
\text { trespassed }\end{array}$ & $\begin{array}{l}\text { Convergent } \\
\text { trespassed }\end{array}$ & $\begin{array}{l}\text { Convergent } \\
\text { trespassed }\end{array}$ \\
\hline
\end{tabular}


Table 4. Metric, morphological, and technological features of the Pororó type points from the Pororó site.

\begin{tabular}{|c|c|c|c|c|c|}
\hline Attributes & Por-05 & Por-06 & Por-09 & Por-11 & Por-12 \\
\hline Raw material & Basalt & Rhyolite & Basalt & Silicified sandstone & Silicified sandstone \\
\hline Total length (mm) & 42 & 42 & - & 35 & 32 \\
\hline Total width (mm) & 18 & 18 & 16 & 14 & 13 \\
\hline Total thickness (mm) & 6 & 5 & 5 & 5 & 4 \\
\hline Width:thickness proportion & $3: 1$ & 3.6:1 & $3.2: 1$ & $2.8: 1$ & $3.2: 1$ \\
\hline Body length (mm) & 33 & 30 & - & 27 & 24 \\
\hline Stem length (mm) & 9 & 12 & 8 & 8 & 8 \\
\hline Active edges length (mm) & 34 & 35 & - & 27 & 23 \\
\hline Shoulders width (mm) & 18 & 18 & 16 & 14 & 13 \\
\hline Neck width (mm) & 13 & 12 & 12 & 10 & 9 \\
\hline Stem width (mm) & 15 & 15 & 14 & 11 & 11 \\
\hline Body shape & Triangle & Triangle & - & Triangle & Triangle \\
\hline Edge lineation & Irregular & Irregular & Straight & Irregular & Irregular \\
\hline Shoulder lineation & Straight & Straight & Expanded & Straight & Straight \\
\hline Neck lineation & Obtuse & Right & Obtuse & Obtuse & Obtuse \\
\hline Stem shape & Concave & Fan & Straight & Concave & Straight \\
\hline Blank type & Flake & Flake & Undefined & Flake & Undefined \\
\hline Reduction method & Bifacial & Unifacial & Bifacial & Bifacial & Bifacial \\
\hline Reduction technique & Pressure & Pressure & Pressure & Pressure & Percussion \\
\hline Retouch method & Bifacial & Bifacial & Bifacial & Bifacial & Bifacial \\
\hline Retouch technique & Pressure & Pressure & Pressure & Pressure & Pressure \\
\hline Organisation of body scars & Parallels trespassed & Parallels trespassed & Parallels trespassed & Parallels trespassed & Parallels trespassed \\
\hline Organisation of stem scars & Selective trespassed & Convergent trespassed & Selective trespassed & Selective trespassed & Selective trespassed \\
\hline
\end{tabular}


Table 5. Metric, morphological, and technological features of points with distinct patterns from the Pororó site.

\begin{tabular}{|c|c|c|c|}
\hline Attributes & Por-02 & Por-27 & Por-28 \\
\hline Raw material & Silicified sandstone & Rhyolite & Flint \\
\hline Total length (mm) & - & 59 & - \\
\hline Total width (mm) & 26 & 18 & 19 \\
\hline Total thickness (mm) & 8 & 5 & 5 \\
\hline Width:thickness proportion & $3.2: 1$ & 3.6:1 & $3.8: 1$ \\
\hline Body length (mm) & - & 47 & 49 \\
\hline Stem length (mm) & 15 & 12 & - \\
\hline Active edges length (mm) & - & 48 & 50 \\
\hline Shoulders width (mm) & 25 & 18 & 19 \\
\hline Neck width (mm) & 17 & 13 & 12 \\
\hline Stem width (mm) & 18 & 16 & - \\
\hline Body shape & Lanceolate & Triangle-blade & Triangle-blade \\
\hline Edge lineation & Convex & Convex & Convex \\
\hline Shoulder lineation & Straight & Straight & Expanded \\
\hline Neck lineation & Obtuse & Obtuse & Obtuse \\
\hline Stem shape & Concave & Bifurcate & - \\
\hline Blank type & Undefined & Flake & Undefined \\
\hline Reduction method & Bifacial & Bifacial & Bifacial \\
\hline Reduction technique & Percussion & Percussion & Percussion \\
\hline Retouch method & Bifacial & Bifacial & Bifacial \\
\hline Retouch technique & Pressure & Pressure & Pressure \\
\hline Organisation of body scars & Parallels trespassed & Parallels trespassed & Selective trespassed \\
\hline Organisation of stem scars & Convergent trespassed & Convergent trespassed & Undefined \\
\hline
\end{tabular}



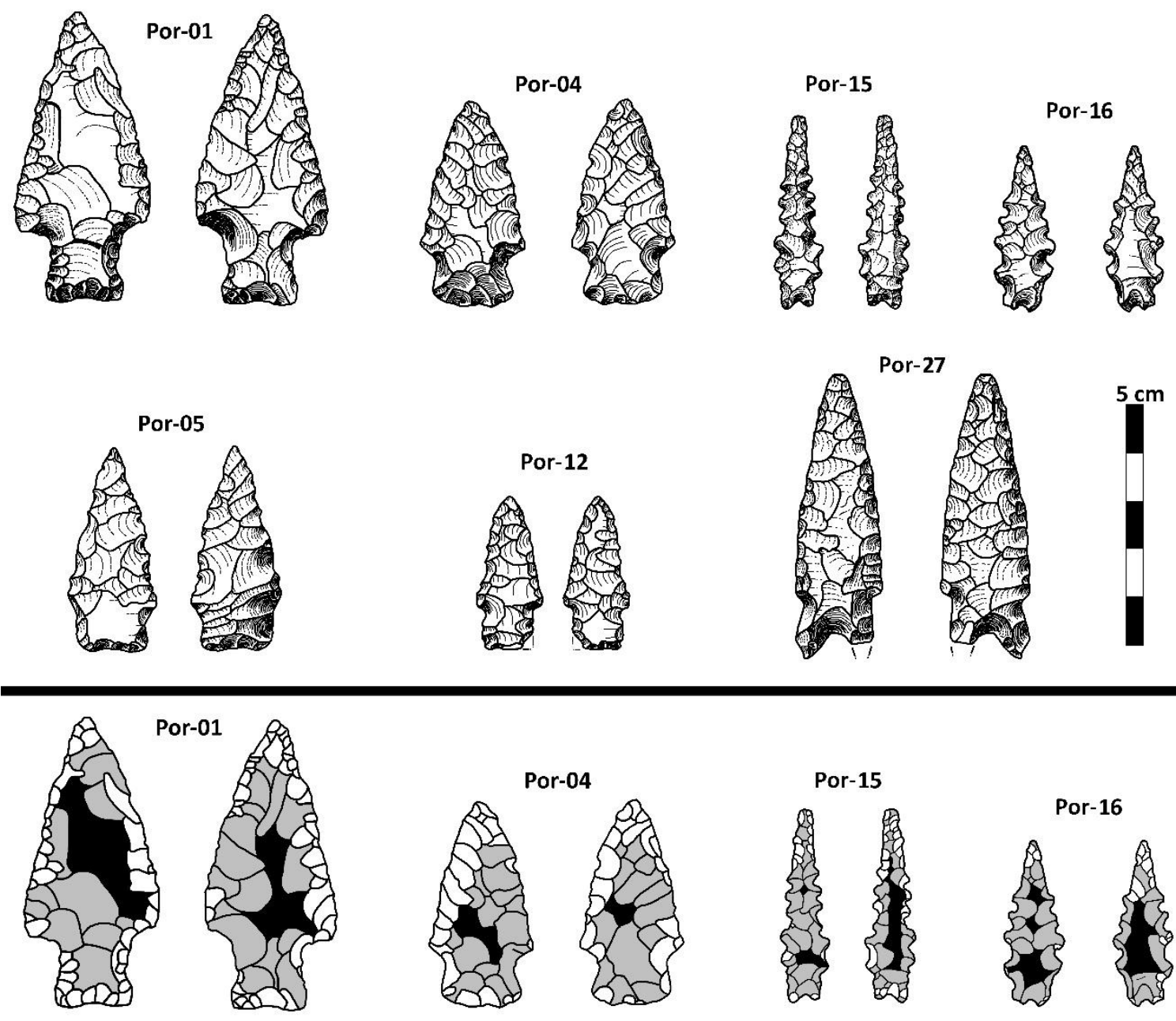

Por-16
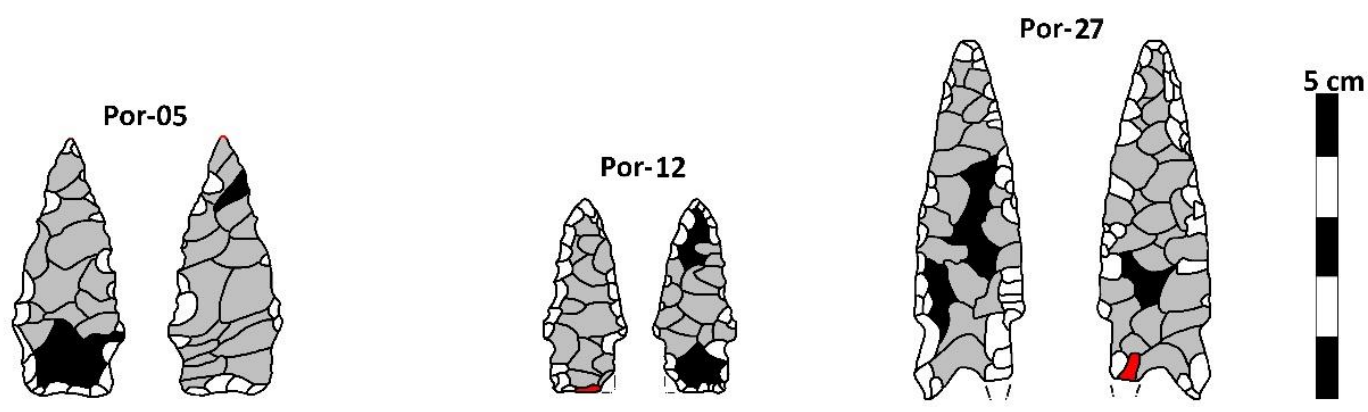

Figure 9. Top: Technical drawings. Bottom: Diachronic schemes. Por-01 and Por-04: Garivaldinense Points. Por-15 and Por-16: Montenegro points. Por-05 and Por-12: Pororó points. Por-27: Pay Paso point. Black represents original blank unmodified areas. Grey represents reduction negatives. White represents retouch negatives. Red represents fractures. All drawings made by the authors.

The points we proposed to call as "Pororó type" could be a Late Holocene innovation within the Garivaldinense lithic industry, but a more accurate chronological distribution is still lacking. These points have dimensions that variate between 32 and $42 \mathrm{~mm}$ in length, 13 to $18 \mathrm{~m}$ in width and 4 to $6 \mathrm{~m}$ in thickness, with 
a width thickness proportion that varies between 2.8:1 and 3.6:1. In morphological terms, these points tend to present a triangular body with irregular edges, straight shoulders and concave or straight stems. In technological terms, these points were made by bifacial reduction by pressure, with parallel trespassed negatives, followed by bifacial retouch by pressure flaking. The Pororó points present metric and morphological features that are very similar to the Garivaldinense points. Technology, however, is quite distinct. In this sense, the Pororó points could be both an innovation within the Garivaldinense lithic industry, as well as a late technological variation of the Garivaldinense points, in which parallel pressure flaking is more commonly used than selective percussion.

Finally, there are three points that do not fit into any of the Garivaldinense, Montenegro or Pororó types. In fact, artefact Por-27 presents features that classifies it within the Pay Paso type definition proposed by Suárez et al. (2018), particularly in morphological terms. In technological terms, the Pay Paso point from the Pororó site is made by bifacial reduction by percussion, with parallel trespassed negatives in the body, convergent trespassed negatives in the stem, and finished by bifacial retouch by pressure flaking. Pay Paso points, however, have never been recorded at Brazilian sites before. According to Suárez et al. (2018), Pay Paso points are common in sites from northwestern Uruguay (along the Brazilian and Argentinian borders). In this sense, the presence of this type in southern Brazilian sites should not be particularly surprising. However, the Pay Paso points from Uruguay are dated between 12,000 and 11,000 BP. The presence of a single Pay Paso point at the Pororó site could suggest the persistence of this type from the Early to the Late Holocene. However, more studies on hunter-gatherer associated sites from Rio Grande do Sul state, especially in the central, western and southern regions, are necessary to understand the possible dispersion and persistence of Pay Paso points throughout Holocene in southern Brazil. The presence of a Pay Paso point in an industry more related to the Garivaldinense culture implies contact of the Pororó people with other groups.

Garcia (2013) carried out a survey of lithic raw materials in the region. Sources of all types of raw materials identified in the lithic points from the Pororó site were found within a radius of $7 \mathrm{~km}$ from the mound. However, sources of flint and silicified sandstone are scarce, with most of the pebbles and cobbles presenting internal 
fractures and/or dimensions that are inadequate for lithic point manufacture. According to Garcia (2013), the number of flakes and the presence of hammerstones and cores at the mound suggests that the points were produced there. Although no preserved evidence of faunal remains has been found, it is known that antlers were used for the production of lithic points, by both percussion and pressure flaking, including at sites associated to the Garivaldinense industry (Mingatos \& Okumura 2020). For all the points where the blank was identified, they were made by the reduction of flakes, probably taken from pyramidal cores, considering this was the most common type of core identified in the site. However, the reduction of cobbles cannot be discarded, particularly on the points made from flint.

The presence of bolas (or boleadeiras) suggests these groups were highly mobile, probably moving to Pampean landscapes to capture animals, since bolas are not efficient on hunting of preys in the local forest. This mobility could result in finding other sources of raw material and probable contact with other cultural groups.

The production of lithic points of different types, although they can be used for the same purposes and are equally efficient as arrow or dart points, is probably related to different uses. Unfortunately, it is impossible to identify their use, since the shafts are not preserved. But it is logical to say, for example, that the biggest points were probably not used for small animals. The diversity of points could also imply their use in different landscapes.

\section{Conclusions}

Although the lithic material evidence, beyond the presence of the points, allow us to describe the Pororó site as a lithic workshop, the production of lithic artifacts was not the only local activity. All evidence suggests the mound as a habitation area (Garcia 2016), as was the case with other similar mounds in Uruguay and southern Brazil that have been called "Cerritos" or "earth mounds" (see Garcia 2019a, 2020). The hunter-gatherers from the Pororó site are probably some of the first groups to build mounds away from the coast in southern Brazil.

In the specific case of the Pororó site, according to the types of lithic artifacts identified by us, the hunter-gatherer inhabitants of the site were associated with the Garivaldinense culture. Compared to the Early Holocene Garivaldinense sites, 
differences probably indicate innovation across time and space, as well as adaptions and possible cultural exchange with other cultural groups. The diversity of types at the site is probably related to different functions or, alternatively, each type could be related to different social divisions of hunters or flintknappers within the group. However, only functional analysis has the power to elucidate these questions.

The region still lacks more complete study. According to Garcia (2016), similar artefacts were found in another four locations within the Lajeado Pororó valley. These locations may also contain mound formations, but only by interventions will it be possible to confirm this hypothesis, since the region is mostly characterized by hills. Even the Pororó site was only identified as a mound during the excavations on the top of a hill. In this sense, more studies are essential to further our knowledge of the region.

\section{Acknowledgements}

We would like to thank Mr. Lucas Somavilla for his concern and interest in contacting archaeologists from the Federal University of Santa Maria after finding the artefacts described in this paper, and also for the donation of his findings to the local museum, and his great collaboration with the excavations on his property. We also thank the former Laboratory of Archaeological Studies and Research of the Federal University of Santa Maria (LEPA-UFSM) for allowing us to access these materials between 2010 and 2014. Our study was funded by FAPESP (process $\mathrm{n}^{\circ}$ 2019/08870-0).

We dedicate this article to the memory of Professor Dr. Saul Eduardo Seiguer Milder, who left us in 2014. Beyond conducting the excavations of the Pororó site, Professor Milder made great contributions to the prehistory of Southern Brazil and, without him, this study wouldn't be possible.

\section{REFERENCES}

Araujo, Astolfo G M 2007 A tradição cerâmica Itararé-Taquara: características, área de ocorrência e algumas hipóteses sobre a expansão dos grupos Jê no sudeste do Brasil. Revista de Arqueologia 20: 9-38. https://doi.org/10.24885/sab.v20i1.225

Cheliz, Pedro M, Moreno de Sousa, João Carlos, Mingatos, Gabriela S, Okumura, Mercedes \& Araujo, Astolfo 2020 A ocupação humana antiga (11-7 mil anos atrás) do Planalto Meridional Brasileiro: caracterização geomorfológica, geológica, paleoambiental e tecnológica de sítios arqueológicos relacionados a três distintas indústrias líticas. Revista Brasileira de Geografia Física 13(6):2553-85. https://doi.org/10.26848/rbgf.v13.6.p2553-2585

Garcia, Anderson Marques 2013 Análise e discussão da tecnologia lítica no sítio arqueológico Pororó, Pinhal Grande - RS. Tarairiú 1(6): 26-56. 
Garcia, Anderson Marques 2016 Cerrito Em Terras Altas: um estudo de caso a partir do Pororó (Pinhal Grande - RS). Tessituras 4(1): 94-116. https://doi.org/10.15210/tes.v4i1.5612

Garcia, Anderson Marques 2019a Cerritos no Brasil. Pensando os mounds do litoral e interior do estado do Rio Grande do Sul. Revista del Museo de Antropología 12(2):41-54. https://doi.org/10.31048/1852.4826.v12.n2.19836

Garcia, Anderson Marques 2019b As pontas do Pororó: análise de artefatos de caçadorescoletores do Rio Grande do Sul. Revista do CEPA 38(50): 1-30.

Garcia, Anderson Marques 2020 Recognizing Different Lifeways and Subsistence Practices through Analysis of the Material Cultures of Mound Sites in Rio Grande do Sul, Brazil. Latin American Antiquity, 31 (2): 308-24. https://doi.org/10.1017/laq.2020.18

Moreno de Sousa, João Carlos 2020 The Technological Diversity of Lithic Industries in Eastern South America during the Late Pleistocene-Holocene Transition. In Ono, Rintaro \& Pawlik, Alfred (eds.) Pleistocene Archaeology - Migration, Technology, and Adaptation. IntechOpen, London. https://doi.org/10.5772/intechopen.89154

Mentz Ribero, Pedro \& Ribeiro, Catrina 1999 Escavações Arqueológicas no Sítio RS-TQ-58: Montenegro, RS, Brasil. Série Documentos da FURG 10: 1-86

Moreno de Sousa, João Carlos \& Okumura, Mercedes 2018 The association of palaeoindian sites from Southern Brazil and Uruguay with the Umbu Tradition: Comments on Suárez et al. (2017). Quaternary International, 467(Part B): 292-6.

https://doi.org/10.1016/j.quaint.2017.11.056

Moreno de Sousa, João Carlos \& Okumura, Mercedes 2020 A New Proposal for the Technological Analysis of Lithic Points: Application for understanding the Cultural Diversity of Hunter Gatherers in Eastern South America. Quaternary International, 562(10): 1-12. https://doi.org/10.1016/j.quaint.2020.07.037

Okumura, Mercedes \& Araujo, Astolfo G M 2016 The Southern Divide: Testing morphological differences among bifacial points from southern and southeastern Brazil using geometric morphometrics. Journal of Lithic Studies 3(1): 107-31. https://doi.org/10.2218/ils.v3i1.1379

Soares, André L R 2005 Contribuição à Arqueologia Guarani: estudo do Sitio Röpke. PhD dissertation. Museu de Arqueologia e Etnologia, Universidade de São Paulo. São Paulo. https://doi.org/10.11606/T.71.2005.tde-21082006-105644

Suárez, Rafael, Piñeiro, Gustavo \& Barceló, Flavia 2018 Living on the river edge: The Tigre site (K-87) new data and implications for the initial colonization of the Uruguay River basin. Quaternary International, 473(Part B): 242-60. https://doi.org/10.1016/j.quaint.2017.08.024

Walker, Mike, Head, Martin H, Berklehammer, Max, Bjorck, Svante, Cheng, Hai, Cwynar, Les, Fisher, David, Gkinis, Vasilos, Long, Antony, Lowe, John, Newnham, Rewi, Rasmussen, Sune Olander \& Weiss, Harvey 2018 Formal ratification of the subdivision of the Holocene Series/Epoch (Quaternary System/Period): two new Global Boundary Stratotype Sections and Points (GSSPs) and three new stages/subseries. Episodes 41(4): 21323. https://doi.org/10.18814/epiiugs/2018/018016 